\title{
Probing the Rhipicephalus bursa Sialomes in Potential Anti-Tick Vaccine Candidates: A Reverse Vaccinology Approach
}

\author{
Joana Couto ${ }^{1,2, *} \mathbb{0}$, Gonçalo Seixas ${ }^{1,2}$, Christian Stutzer ${ }^{3}$, Nicholas A. Olivier ${ }^{4,5}$, Christine Maritz-Olivier ${ }^{3}$, \\ Sandra Antunes $1,2, *\left(\mathbb{C}\right.$ and Ana Domingos ${ }^{1,2}$ (i)
}

1 Instituto de Higiene e Medicina Tropical, Universidade Nova de Lisboa, Rua da Junqueira, 100, 1349-008 Lisboa, Portugal; gseixas@ihmt.unl.pt (G.S.); adomingos@ihmt.unl.pt (A.D.)

2 Global Health and Tropical Medicine, Instituto de Higiene e Medicina Tropical, Universidade Nova de Lisboa (GHTM-IHMT-UNL), Rua da Junqueira, 100, 1349-008 Lisboa, Portugal

3 Division of Genetics, Department of Biochemistry, Genetics and Microbiology, Faculty of Natural and Agricultural Sciences, University of Pretoria, Pretoria 0002, South Africa; christian.stutzer@gmail.com (C.S.); christine.maritz@up.ac.za (C.M.-O.)

4 Department of Plant and Soil Sciences, University of Pretoria, Pretoria 0002, South Africa; nicky.olivier@fabi.up.ac.za

5 Forestry and Agricultural Biotechnology Institute (FABI), University of Pretoria, Pretoria 0002, South Africa

* Correspondence: jmgtcouto@gmail.com (J.C.); santunes@ihmt.unl.pt (S.A.); Tel.: +351-213-652-600 (J.C.); Fax: +351-213-652-105 (J.C.)

\section{check for} updates

Citation: Couto, J.; Seixas, G.; Stutzer, C.; Olivier, N.A.; Maritz-Olivier, C.; Antunes, S.; Domingos, A. Probing the Rhipicephalus bursa Sialomes in Potential Anti-Tick Vaccine Candidates: A Reverse Vaccinology Approach. Biomedicines 2021, 9, 363. https://doi.org/10.3390/ biomedicines 9040363

Academic Editor:

Gabriela Santos-Gomes

Received: 15 January 2021

Accepted: 28 March 2021

Published: 31 March 2021

Publisher's Note: MDPI stays neutral with regard to jurisdictional claims in published maps and institutional affiliations.

Copyright: (c) 2021 by the authors. Licensee MDPI, Basel, Switzerland. This article is an open access article distributed under the terms and conditions of the Creative Commons Attribution (CC BY) license (https:/ / creativecommons.org/licenses/by/ $4.0 /)$.
Abstract: In the wake of the 'omics' explosion of data, reverse vaccinology approaches are being applied more readily as an alternative for the discovery of candidates for next generation diagnostics and vaccines. Promising protective antigens for the control of ticks and tick-borne diseases can be discovered by mining available omics data for immunogenic epitopes. The present study aims to explore the previously obtained Rhipicephalus bursa sialotranscriptome during both feeding and Babesia infection, to select antigenic targets that are either membrane-associated or a secreted protein, as well as unique to the ectoparasite and not present in the mammalian host. Further, they should be capable of stimulating $\mathrm{T}$ and $\mathrm{B}$ cells for a potential robust immune response, and be non-allergenic or toxic to the host. From the R. bursa transcriptome, 5706 and 3025 proteins were identified as belonging to the surfaceome and secretome, respectively. Following a reverse genetics immunoinformatics pipeline, nine preferred candidates, consisting of one transmembrane-related and eight secreted proteins, were identified. These candidates showed a higher predicted antigenicity than the Bm86 antigen, with no homology to mammalian hosts and exposed regions. Only four were functionally annotated and selected for further in silico analysis, which examined their protein structure, surface accessibility, flexibility, hydrophobicity, and putative linear B and T-cell epitopes. Regions with overlapping coincident epitopes groups (CEGs) were evaluated to select peptides that were further analyzed for their physicochemical characteristics, potential allergenicity, toxicity, solubility, and potential propensity for crystallization. Following these procedures, a set of three peptides from the three R. bursa proteins were selected. In silico results indicate that the designed epitopes could stimulate a protective and long-lasting immune response against those tick proteins, reflecting its potential as anti-tick vaccines. The immunogenicity of these peptides was evaluated in a pilot immunization study followed by tick feeding to evaluate its impact on tick behavior and pathogen transmission. Combining in silico methods with in vivo immunogenicity evaluation enabled the screening of vaccine candidates prior to expensive infestation studies on the definitive ovine host animals.

Keywords: tick; vaccine; sialotranscriptome; reverse vaccinology; immunoinformatics

\section{Introduction}

Tick and tick-borne diseases are an increasing threat for both human and animal health [1]. The multi-host hard tick species, Rhipicephalus bursa, has a wide distribution 
throughout the Mediterranean basin and transmits several pathogens of economic importance in ungulates (i.e., cattle, sheep, and goats) from several genera, including Babesia, Anaplasma, Theileria, Rickettsia, and Coxiella [2]. Recently, R. bursa has been implicated in the transmission of several zoonotic pathogenic agents highlighting its impact in human health [3]. This tick is the primary vector of Babesia ovis, a highly pathogenic hemoparasite in small ruminants, recognized for having an important socioeconomic impact, primarily in low income countries, related with production losses and costs of the animal treatment [4]. Moreover, B. ovis is present in all developmental stages of R. bursa species since it has the capacity for transovarial and transstadial transmission [5].

The (re)emergence of ticks and tick-borne diseases and the lack of safer and more effective control strategies have reinvigorated research efforts by the scientific community to explore ways to control ticks and, subsequently, their associated diseases. Biological control [6], acaricides [7,8], resistant production breeds [9], and vaccines [10-12] are being proposed and readily tested for tick population control. Vaccines are one of the most environmentally friendly pharmaceutical products [13], as well as effective prophylactic treatment [14], used in infectious disease control. In tick research, the development and commercialization of novel vaccines [15] have been hindered by different factors $[16,17]$ such as the lack of knowledge regarding tick-host interactions and tick biology. Particularly, transmissionblocking vaccines are considered very attractive tools for vector-borne disease control since they can affect the vector's biology and behavior, thereby interfering with its capacity to transmit diseases [18-20]. Traditionally, vaccines confer protection by stimulating a humoral response mediated by antibodies [21]. These antibodies are involved in recognition and binding of the foreign antigen resulting in neutralization, agglutination, precipitation, as well as complement activation using chemoattractants to facilitate inflammation [22].

To date only one subunit anti-tick vaccine has been commercialized, based on a surface exposed 89 kDa glycosylphosphatidylinositol (GPI)-linked glycoprotein, Bm86, originally found in Rhipicephalus microplus midgut tissues [23,24]. Vaccination with this antigen can induce a protective immune response mediated mainly by host humoral response and the complement system, damaging the tick midgut wall and leading to a decrease in tick survival and diminished capacity to produce viable progeny [25-27]; however, with a efficacy depending on the tick species and strains [11].

Thus, a panoply of targets must be studied and tested to increase the current antigen repertoire for use in novel anti-tick vaccines and improve their efficiency. Immunoinformaticsbased approaches have been recently applied to catalogue potential protective antigens, reducing cost and time in anti-tick vaccine development [25,28-30]. Reverse vaccinology (RV) is an approach exploring available omics data and in silico tools to select a great amount of predicted antigenic proteins potentially capable of inducing a protective immune response in vivo [21,31-34]. A combination of such techniques is steadily being implemented to develop novel and effective vaccines against several infectious diseases, including parasitosis [35-40]. These approaches have been already used on tissue-specific tick omics data in the pursuit of potential protective candidates [26,30,41-43]. Immunoinformatics focusing tick sialomics data are of particular interest since tick secreted salivary proteins can closely influence the host immune response at the vector feeding site, as well as enable pathogen dissemination and multiplication inside the host [44-48]. Even though functional redundancy is expected in tick salivary gland proteins [49], transcriptomic and proteomic studies of this tissue represents a collection of pharmacoactive molecules with therapeutic exploitation potential [48]. Moreover, peptide and multi-epitope constructs can be designed to synergize the impact of recognizing multiple antigens [50] and overcoming functional redundancy, as well as minimizing the side-effects caused by the immunization of an entire protein [51].

Regarding topology, proteins that contain extracellularly exposed portions on the cell outer membranes (surfaceome) or that are secreted into the extracellular space (secretome) are considered suitable antigens for vaccine development due to better accessibility to the immune system [26,32], as opposed to cytoplasmic proteins that can rather be considered 
for small molecule drug development [26,32,52]. Targeting a membrane-related protein may also interfere with the tick capacity to transmit or acquire pathogens if produced antibodies directly block the parasite from crossing the midgut or salivary glands barriers, as observed in other vectors, such as mosquitoes [18,53]. The tick secretome represents a chemical pool, critical for tick feeding and life cycle, as well as pathogen transmission. Thus, tick salivary secretions could be the core for the development of novel therapeutics for host disorders [48,54] or anti-tick and transmission blocking vaccines [55] as in the case of Salp15 and Borrelia burgdorferi transmission by Ixodes ticks [56].

Therefore, this study aims to scrutinize available high-throughput omics data, using a RV approach, focusing on the Rhipicephalus bursa-Babesia ovis (vector-pathogen) interface in order to identify antigenic peptides from tick sialoproteins that could be promising candidates for future vaccination trials. For this, computational methods have been combined to predict $\mathrm{B}$ and $\mathrm{T}$ cell epitopes, as well as its topology, hydrophobicity, polarity, solubility, and other physicochemical aspects [57], in order to select candidates comprising all the requirements for a suitable vaccine or even for disease diagnosis and disease therapy [58]. Such exposed antigens could become targets for peptide-based therapeutics if they present high antigenicity and no toxicity to the host.

\section{Material and Methods}

\subsection{Rhipicephalus bursa Sialotranscriptomes: New Assembly}

The data analyzed was obtained previously by Antunes et al. [59]. Briefly, R. bursa female ticks were obtained under different conditions: uninfected-unfed ticks, uninfectedfed ticks, and B. ovis infected-fed ticks. Salivary glands were isolated, RNA extracted, and two replicates per condition were used for RNA sequencing in a HiSeq 2500 sequencer (Illumina, CA, USA) after quality assessment and library construction. Cluster generation was performed, followed by $2 \times 100$ cycle sequencing reads separated by a paired-end turnaround. The raw fastq files deposited at the National Center for Biotechnology Information (NCBI) under the accession numbers SRR4428986, SRR4428987 and SRR4428988 [59] were re-analyzed under the present study. For this, sequence reads were quality filtered and trimmed using Trimmomatic [60] and the transcriptomes reassembled using Trinity [61]. To evaluate the completeness of the assemblies, BUSCO [62] analyses were performed using the Arthropoda dataset as a reference.

\subsection{In Silico Characterization of Rhipicephalus bursa Protein Coding Sequences}

A filtering process was performed using various bioinformatics tools to identify protein coding open-reading frames, topological features, antigenic regions, and annotate potential candidates. See Figure 1 for the experimental outline.

Open reading frames (ORF) in transcriptome contigs were predicted using TransDecoder [62]. InterProScan [63] was used to classify the predicted protein sequences in terms of signal peptide and transmembrane regions with SignalP (v. 4.0) [64] and TMHMM (v. 2.0) $[65,66]$, respectively. Redundant (or highly similar; identity $>90 \%$ ) and closely related protein families were analyzed with CD-HIT v4.8.1 [67], and only the representative sequences were used in subsequent analyses.

The online server Vaxijen (v. 2.0) was used to select the antigenic proteins [68]. Based on the immunogenicity of the only commercially available anti-tick vaccine, Bm86, a threshold of 0.7 was applied [30].

Then, to select antigens that differ from possible vertebrates used in future vaccination trials, the Geneious R8.1 software was used to search for homology between the R. bursa dataset and the mammalian hosts amino acid databases (Mus musculus, Oryctolagus cuniculus and Ovis aries).

Next, CELLO (v. 2.5) [69], WoLF PSORT [70], and BUSCA [70] online servers were used to select the surfaceome and secretome using the names "plasma membrane" and "extracellular" as filters. SignalP (v. 5.0) [71], big-PI [72], GPI-SOM [73], Phobius [74], TMHMM (v. 2.0), CCTOP (v. 1.0) [75], and SACS TMHMM [75] programs were used for the selection 
of membrane-related antigens with exposed regions ("outside" or "non-cytoplasmatic", with regions greater than 15 a.a.) without signal peptide neither glycosylphosphatidylinositol (GPI)-anchor in all the in silico results.

For the selection of secreted antigens, the same approach was used including proteins with signal peptide but no GPI-anchor in all the in silico results.

Finally, the selected R. bursa proteins were functionally annotated by BLASTp (https: / / blast.ncbi.nlm.nih.gov / Blast.cgi?PAGE=Proteins, accessed on 30 October 2019) against the NCBI non-redundant (nr) and Arthropoda (6656) databases using the PAM70 matrix (E value $<1 \times 10^{-1}$, coverage: $50-100 \%$, identity: $50-100 \%$ ). Only the proteins functionally annotated were further used in the ensuing analysis.

\section{ORFs and Proteomics}

The occurrence of the predicted ORFs from the transcriptomes in the previously published R. bursa sialoproteomic data was assessed. The proteomic data was obtained previously by Couto et al. [76]. Briefly, four groups of ticks were generated considering the conditions of uninfected unfed, uninfected fed, infected unfed, and infected fed, and salivary glands from each were dissected for protein extraction. Protein extracts were precipitated and digested, until the peptides were desalted; samples were analyzed via reverse phase liquid chromatography coupled online with mass spectrometry (RP-LC-MS/MS) using an Ekspert nLC 415 system combined to a 6600 TripleTOF $^{\circledR}$ mass spectrometer (AB SCIEX ${ }^{\circledR}$, MA, USA) through information-dependent acquisition (IDA) followed by sequential windowed data independent acquisition of the total high-resolution mass spectra (SWATH). The BLASTP was used to perform a local analysis using the predicted Transdecode ORFs from the sialotrancriptome as protein database and the respective peptides from proteomic analysis as a query (E value cutoff of 0.0001 , word-size of 7 for a shorter input sequence).

\section{Protein Structure and Epitope Exposure}

The presence of coiled-coil (C), alpha helix $(\mathrm{H})$, and beta sheet $(\mathrm{E})$ was predicted using the NetSurfP-2.0 [75] and BepiPred 2.0 (structural frame) [77] programs. The Chou and Fasman prediction method [78] (from IEDB Analysis Resource, v. 2.22, http://tools.iedb. $\mathrm{org} / \mathrm{bcell} /$, accessed on 30 October 2019) was used to predict beta turns within the amino acid sequence, considering probable turn regions those with values higher than 1 .

The surface accessibility of the amino acids was evaluated using the Emini prediction method [78] (from IEDB Analysis Resource, v. 2.22, threshold of 1, http://tools. iedb.org/bcell/, accessed on 30 October 2019) and BepiPred 2.0 (surface frame) program. Features such as flexibility and hydrophobicity were evaluated using the KarplusSchultz [79] and Parker [80] methods (from IEDB Analysis Resource, v. 2.22, threshold of 1, http:/ / tools.iedb.org/bcell/, accessed on 30 October 2019), respectively.

\section{Prediction of B and T Cell Epitopes}

Potential immunogenetic epitopes were predicted using linear B-cell epitope predictors: the Kolaskar and Tongaonkar method [81] (from IEDB Analysis Resource, v. 2.22, threshold of 1, http:/ / tools.iedb.org/bcell/, accessed on 30 October 2019), the predicting antigenic peptides online server (from Immunomedicine Group, http: / /imed.med.ucm. es/Tools/antigenic.pl, accessed on 30 October 2019), BepiPred 1.0 [80] (from DTU Bioinformatics, http:/ / www.cbs.dtu.dk/services/BepiPred-1.0/, accessed on 30 October 2019), and BepiPred 2.0 (epitope frame) program.

T-cell epitopes were also predicted using all prediction method versions. MHC-I Binding Predictions program (from IEDB Analysis Resource, v. 2.22, http:/ / tools.iedb.org/mhci/, accessed on 30 October 2019) was used to predict epitopes with high affinity to human, mouse, and rat MHC-I. Prediction of MHC-II binding epitopes was obtained using the MHC-II Binding Predictions (from IEDB Analysis Resource, v. 2.22, using all method versions, selecting 12-18-mer peptides, http://tools.iedb.org/mhcii/, accessed on 30 October 2019) and the MHC2Pred (http:/ / crdd.osdd.net/raghava/mhc2pred/, accessed on 30 October 
2019) programs for human and mouse MHC-II databases. Predicted T-cell epitopes containing a percentile rank lower or equal to one were selected to identify the representative epitopes using the Epitope Cluster Analysis tools (from IEDB Analysis Resource, v. 2.22, http://tools.iedb.org/cluster/, accessed on 30 October 2019). NetChop (v. 3.1) [82] and PCPS (http:/ /imed.med.ucm.es/Tools/pcps/index.html, accessed on 30 October 2019) programs were used to explore if, after proteasomal processing, the epitope generated could be an MHC binder, which means that could be presented in the host immune system, processed, and ultimately induced in the host humoral and cellular immune pathway.

\section{Peptide Properties}

Amino acid sequence of selected peptides was used to predict it physicochemical characteristics including molecular weight $(\mathrm{Da})$, theoretical isoelectric point $(\mathrm{pI})$, instability index, grand average of hydropathicity (GRAVY), and aliphatic index, using Expasy ProtParam server (http:/ / expasy.org / cgi-bin/ protpraram, accessed on 30 November 2019). The allergenicity of the epitopes was predicted by the online servers AllergenFP (v. 1.0) [83], AllerTop (v. 2.0) [84], and AllerCatPro (v. 1.7) [85]. Protein-Sol was used to predict the peptide solubility ( $>0.8$ values indicate a soluble molecule) [86] and CRYSTALP2 for crystallization propensity [87]. Post-translational modification sites in the peptides were predicted using ModPred [88] and PROSITE [89], regarding its impact on protein/peptide production, structure and function [90]. The hemolytic, anti-angiogenic or toxic properties of the selected peptides were analyzed using HemoPI (all SVM methods were used; SVM scores ranges between 0 and 1, i.e., 1 very likely to be hemolytic, 0 very unlikely to be hemolytic) [91], AntiAngioPred (NT15 AAC and whole peptide AAC prediction methods were used; threshold -0,2,) [92], and ToxinPred (all SVM methods were used; E value 10; threshold 0.0) [93], respectively. For comparison, all these analysis were performed for the published synthetic multi-epitope peptide SBm $7462{ }^{\circledR}[94]$ ), which has demonstrated to be a protective candidate for a next generation anti-tick vaccine $[94,95]$.

\section{Results and Discussion}

Before searching for promising antigens, the previously published Sequence Read Archives regarding uninfected-unfed, uninfected-fed, and B. ovis infected-fed R. bursa salivary glands RNA sequencing [59] were reassembled and assessed for completeness using BUSCO analysis [62] and a reference database of 1066 conserved arthropod genes (see Table 1).

Table 1. BUSCO statistics for each Rhipicephalus bursa sialotranscriptome assembly against an arthropod database. Conserved BUSCO genes were assigned to four classes of genes: missing, fragmented, duplicated, and complete.

\begin{tabular}{cccc}
\hline Dataset & Babesia ovis Infected and Fed & Uninfected and Fed & Uninfected and Unfed \\
\hline Scaffolds $(\#)$ & 70535 & 63942 & 58670 \\
\hline Assembly size (Mbp) & 64.5 & 67.6 & 47.3 \\
\hline N50 (bp) & 1856 & 2266 & 1522 \\
\hline $\begin{array}{c}\text { Number of conserved arthropod } \\
\text { genes in BUSCO reference set }\end{array}$ & & 1066 & $692(64.9 \%)$ \\
\hline Complete and single-copy & $683(64.1 \%)$ & $690(64.7 \%)$ & $200(18.8 \%)$ \\
\hline Complete and duplicated & $273(25.6 \%)$ & $312(29.3 \%)$ & $125(11.7 \%)$ \\
\hline Fragmented & $78(7.3 \%)$ & $36(3.4 \%)$ & $49(4.6 \%)$ \\
\hline Missing & $32(3 \%)$ & $28(2.6 \%)$ & \\
\hline
\end{tabular}

The assembly of the sequencing reads of the salivary glands of B. ovis-infected-fed $R$. bursa ticks yielded a transcriptome with 70,535 scaffolds, a total assembly size of $64.5 \mathrm{Mbp}$, and a scaffold N50 length of $1856 \mathrm{bp}$. The BUSCO completeness report of the assembly indicated that $89.7 \%$ complete BUSCOs were obtained for this assembly. 
Specifically, there were 956 complete (683 complete and single-copy; 273 duplicated), 78 fragmented, and 32 missing BUSCOs. Similarly, a final percentage of complete orthologous genes of $94.0 \%$ (uninfected -fed) and $83.7 \%$ (uninfected-unfed), respectively, were determined for the remaining uninfected R. bursa sialotranscriptomes. It is unlikely to produce a complete BUSCO transcriptome and it is accepted for non-model organisms, such as ticks, to obtain complete scores ranging from $50 \%$ to $90 \%$ [96]. This is an indicator of a proper transcriptome assembly; thus, these are acceptable ranges for percentage of completeness relative to other RNAseq assemblies in the field $[43,97]$. Reassembled and complete transcriptomes were considered for the next phase.

\subsection{Feeding and Pathogen Transmission: Selection of Targets}

The systematic workflow of an RV approach must focus on filtering ideal antigens that provide a robust, long-lasting, and deliverable immune response, such as the humoral response, which ultimately interferes with the host-vector-pathogen triad [20]. Thus, the features of an ideal antigen for anti-tick vaccines includes: being a pivotal molecule on tick/pathogen biology, not being homologous to the mammalian host, encoded by a single gene, expressed across life stages and tick tissues, and capable of inducing $B$ and T cells to incite an immunological response without allergenic, hemolytic, and toxic effects [14,98]. Such humoral response is linked to topological features, such as extracellular or intramembrane location, and the presence of coincident epitope groups (CEGs) (also known as "immunological kernels"), are accessible protein regions containing overlapped B and T cell epitopes with ideal chemo-physical properties $[52,99,100]$.

Therefore, the dataset from fed-infected tick salivary glands were analyzed. They were found to correspond to proteins involved in blood feeding and parasite transmission. These processes are intrinsically related to vector survival and competence [101]. Moreover, we performed in silico screening for the antigenic surfaceome and secretome using different filters (Figure 1).

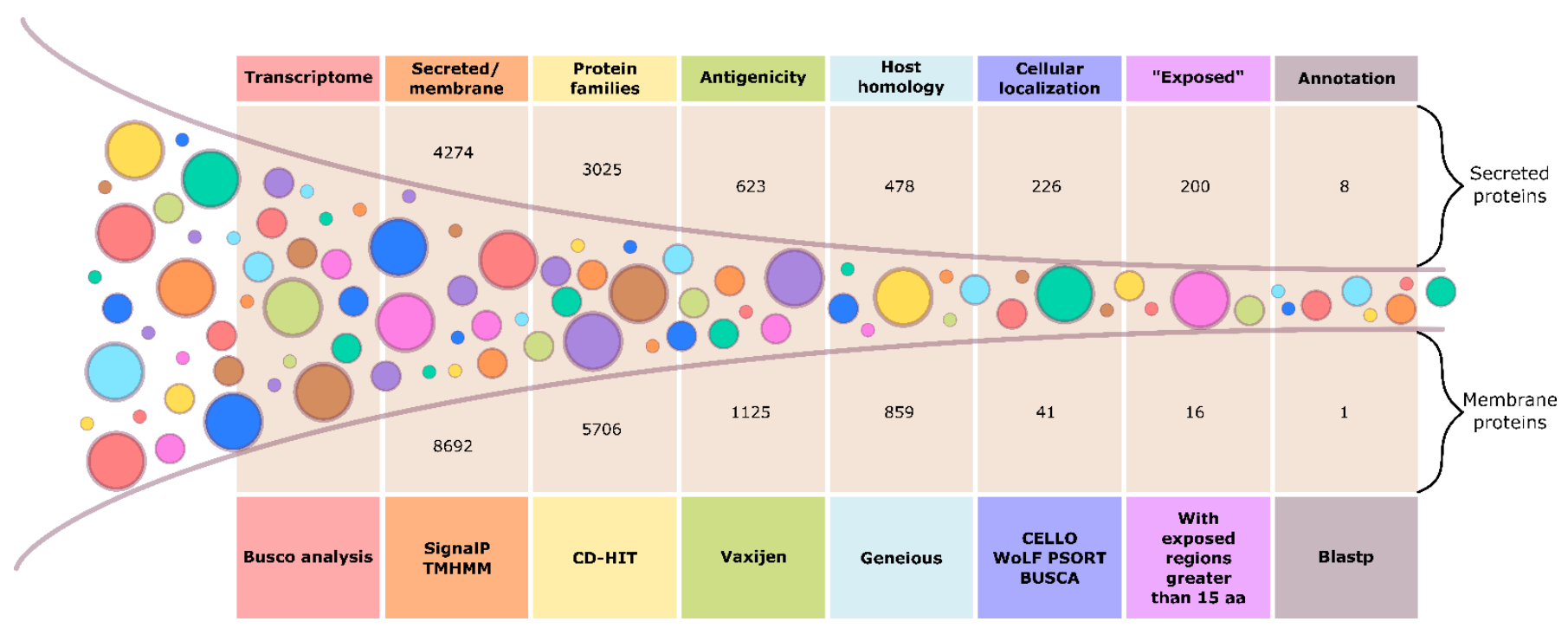

Figure 1. Graphical depiction of the reverse vaccinology (RV)-based methodology used for antigen screening. From the "fed and infected" R. bursa sialotranscriptome dataset, the secretome (secreted proteins) and the surfaceome (membrane proteins) were differentiated using SignalP and TMHMM (software package, standalone installation or online server, current v.2.0.). Several filters were applied using different programs to filter promising targets.

Transcripts containing membrane-related regions were filtered and analyzed regarding its protein antigenicity, homology to vertebrate hosts, cell localization, and annotated function (Supplementary material-Spreadsheet S1). From the transcriptomic selected dataset, 8692 sequences were predicted to be membrane-related proteins that were asso- 
ciated with 5706 different protein family clusters. Each representative of every protein family was investigated for its predicted antigenicity and 1125 proteins were found to be probable antigens in comparison to the Bm86 tick vaccine antigen (Vaxijen score $\geq 0.7$ ). From these predicted antigenic proteins, 859 presented no homology to the vertebrate hosts, warranting the probability of inducing a target tick-specific immune response in the host animal and not leading to an auto-immune phenomenon [25,30,52]. In total, 16 proteins were predicted to be localized in the cell plasma membrane, as a transmembrane protein without signal peptide or GPI anchor (i.e., secreted or anchored). Following this analysis, a putative lipid raft-associated protein containing a MARVEL domain (M_MARVEL, DN25304, EEC06674.1) was identified.

Transcripts containing signal peptides were identified in a similar way as previously described for the transmembrane-related proteins (Supplementary material-Spreadsheet S2). From the current dataset, 4274 sequences contained signal peptides clustered into 3025 different protein families. Predicted antigenicity via Vaxijen identified 623 proteins that presented higher probability of being antigenic relative to Bm86. Alignment and homology analysis indicated that 478 proteins to be tick-specific and non-related to vertebrate hosts (Figure 1). About 200 transcripts were predicted to be extracellular with no predicted membrane-spanning regions following the signal peptide region. Finally, seven putative proteins were identified consisting of two glycine-rich proteins (DN21364, DN28608), an evasin (S_EVASIN, DN20966, AST14849.1), a ricin (S_RICIN, DN33470, EEC03321.1), an antimicrobial peptide (DN7637), and two proteins related to heterodimerization interface (DN16497) and coagulation (DN45898).

\subsection{In Silico Characterization of Selected Candidates}

In this study, one membrane-related (MARVEL) and two secreted (EVASIN, RICIN) proteins were selected to proceed for specific immunoinformatic analysis, since their putative function and occurrence in previously published proteomic data highlighted them as promising targets for anti-tick or disease transmission blocking vaccine development. While MARVEL can be found in the infected-fed, uninfected-fed, and uninfected-unfed conditions of R. bursa sialoproteomic data, EVASIN and RICIN are only found in the infected-fed state. This suggests the persistence of MARVEL in the tick cellular machinery as a static membrane protein, while EVASIN and RICIN could be strongly or exclusively linked to infection and feeding.

For each target, prediction methods were used to assess protein structure (Table 2) and putative epitope exposure for a better identification of exposed and immunogenic regions, including B and T (Supplementary material-Spreadsheet S3-S5) cell epitopes. Since very limited information on MHC alleles from sheep and other host vertebrates of R. bursa ticks is currently available, "pan-computational methods" predictions were used, as described before [102]. The available allelic datasets from different but well-known hosts, such as humans, mice, and rats, were used to extrapolate the vertebrate host with unknown alleles such as sheep. 
Table 2. Topology and structure properties of the selected targets. Several bioinformatic tools were used to obtain this data. (Prosite $\left(^{*}\right)$, VectorBase $\left(^{* *}\right)$, Phobius (a), TMHMM (b), CCTOP (c), SACS TMHMM (d), and SignalP (e).)

\begin{tabular}{|c|c|c|c|c|c|c|c|c|}
\hline $\begin{array}{l}\text { Protein } \\
\text { Name }\end{array}$ & Length (aa) & MW (Da) & pI & Functional Domains & $\begin{array}{c}\text { Transmembrane } \\
\text { Domains }\end{array}$ & $\begin{array}{l}\text { Extracellular } \\
\text { Domains }\end{array}$ & SP & GPI \\
\hline MARVEL & 155 & 16508.53 & 9.03 & $\begin{array}{c}\text { Contains: } \\
\text { leucine zipper domain } \\
\text { (pos. 24-52)* } \\
\text { and Marvel domain } \\
\text { (pos. 29-157 from } \\
\text { ISCW003585) }\end{array}$ & $\begin{array}{l}\text { Pos. 29-52, 64-84, } \\
96-117,129-150 \text { a } \\
\text { Pos. 28-50, 63-85, } \\
\text { 98-120, 127-149 b } \\
\text { Pos. 29-52, 62-85, } \\
\text { 95-117, 127-149 c } \\
\text { Pos. 28-50, 63-85, } \\
\text { 98-120, 127-149 d }\end{array}$ & $\begin{array}{c}\text { Pos. 1-28, 85-95, } \\
151-155 \text { a } \\
\text { Pos. } 1-27,86-97, \\
150-155 \text { b } \\
\text { Pos. } 1-28,86-94, \\
150-155 \text { c } \\
\text { Pos. } 1-27,86-97 \\
150-155 \text { d }\end{array}$ & No & No \\
\hline EVASIN & 164 & 17681.84 & 4.20 & $\begin{array}{l}\text { Homology to an evasin } \\
\text { protein } \\
\text { (AST14849) }\end{array}$ & None & $\begin{array}{l}\text { Pos. 28-164 a } \\
\text { Pos. 1-164 b } \\
\text { Pos. 29-164 c }\end{array}$ & $\begin{array}{l}\text { Yes } \\
\text { Pos. 1-27 a } \\
\text { Pos. } 1-26 \mathrm{e}\end{array}$ & No \\
\hline RICIN & 133 & 14401.49 & 8.19 & $\begin{array}{l}\text { Homology to a } \\
\text { hypothetical protein } \\
\text { which contains a } \\
\text { Ricin-type beta-trefoil } \\
\text { lectin domain } \\
\text { (EEC03321) }\end{array}$ & None & $\begin{array}{l}\text { Pos. 1-133 a } \\
\text { Pos. 1-133 b } \\
\text { Pos. } 40-133 \mathrm{c}\end{array}$ & $\begin{array}{l}\text { Yes } \\
\text { Pos. } 1-39 \text { c } \\
\text { Pos. } 1-37 \text { e }\end{array}$ & No \\
\hline
\end{tabular}

Regions with overlapping CEGs were thoroughly examined to screen ideal features for efficient production, using bioinformatic tools to evaluate physicochemical characteristics, post-translational modification sites, propensity for solubility and crystallization, allergenicity, and toxicity (Table 3). Depending on these characteristics, the production and solubilization of these peptides or proteins are different. Finally, as far as possible, the potential negative effects on the host should be predicted a priori to testing a potential vaccine [103]. Many highly reactive proteins identified from various parasites (including mites and helminths) are prone to cause allergic reactions in the host [14,104]. Therefore, predicting allergenicity and anti-angiogenic or toxic properties of the selected proteins/peptides are also required when screening for a promising candidate [13]. Taking all the aforementioned components into account, the three chosen candidates are discussed in the following sections. 


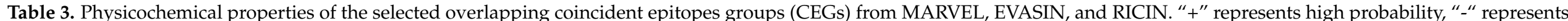
low probability.

\begin{tabular}{|c|c|c|c|c|c|c|c|c|c|c|c|}
\hline Protein Name & $\begin{array}{l}\text { CEG Length } \\
\text { (aa) }\end{array}$ & $\begin{array}{l}\text { Molecular } \\
\text { Weight (Da) }\end{array}$ & pI & $\begin{array}{l}\text { Instability } \\
\text { Index }\end{array}$ & GRAVY & Aliphatic Index & $\begin{array}{c}\text { Allergenicity } \\
\text { (AllerFP/AllerTop/AllerCatPro) }\end{array}$ & $\begin{array}{c}\text { Solubility and } \\
\text { Crystallization Propensity } \\
\text { (Protein-Sol, CRYSTALP2) }\end{array}$ & $\begin{array}{l}\text { Hemolytic } \\
\text { Potency } \\
\text { (HemoPI) }\end{array}$ & $\begin{array}{l}\text { Anti-Angiogenic } \\
\text { Property } \\
\text { (AntiAngioPred) }\end{array}$ & $\begin{array}{c}\text { Toxicity } \\
\text { Prediction } \\
\text { (ToxinPred) }\end{array}$ \\
\hline MARVEL & 27 & 2698.98 & 9.5 & 74.70 & 0.167 & 71.85 & $-/+/-$ & 0.669, none & $\begin{array}{l}0.01,0.49,0.44 \\
0.00,0.49\end{array}$ &,++ &,,,---- \\
\hline RICIN & 41 & 4243.91 & 6.43 & 57.47 & 0.285 & 97.56 & $-1+/-$ & 0.659, none & $\begin{array}{l}0.00,0.48,0.47 \\
\quad 0.00,0.48\end{array}$ &,-- &,,,---- \\
\hline $\mathrm{SBm} 7462^{\circledR}$ & 45 & 5056.78 & 6.87 & 49.21 & -0.300 & 47.78 & $-/-/-$ & 0.484 , none & $\begin{array}{c}0.45,0.35,0.37 \\
0.00,0.35\end{array}$ &,++ &,,,+-+- \\
\hline
\end{tabular}




\subsection{Putative MARVEL Domain-Containing Protein}

MARVEL domain-containing proteins generally present an M-shaped topology (four transmembrane-helix region architecture with cytoplasmic $\mathrm{N}$ - and C-terminal regions) and function in cholesterol-rich membrane apposition events, such as biogenesis of vesicular transport carriers or tight junction regulation [105]. The putative MARVEL protein identified in this study is 155 amino acids long, thus lacking a signal peptide or GPI-anchor and containing four transmembrane and three extracellular domains (Table 2, Figure 2). From the predicted extracellular domains, only an $\mathrm{N}$-terminal region containing 27 amino acids was predicted to be majorly exposed, with a low structural complexity and a single predicted post-translational modification (PTMs) and glycosylation (Figure 2, Supplementary material-Spreadsheet S3). Such PTMs are associated with protein structure, stability, activity, trafficking, and protein-protein interactions [90]. All of these targeted characteristics are being considered for a potential vaccine candidate. The propensity of this protein to induce the humoral pathway was evaluated by predicting in silico the B and $\mathrm{T}$ cell epitopes (Figure 2, Supplementary material—Spreadsheet S3). The three B cell epitope predictors showed that this segment of the MARVEL protein could be presented directly to B cells and induce a humoral response. Additionally, this protein portion has predicted protease cut sites (pos. 32-37) that could originate peptides that would enable presentation through MHC I (pos. 18-27) and II (pos. 4-12) (Figure 2, Supplementary material—Spreadsheet S3).

A

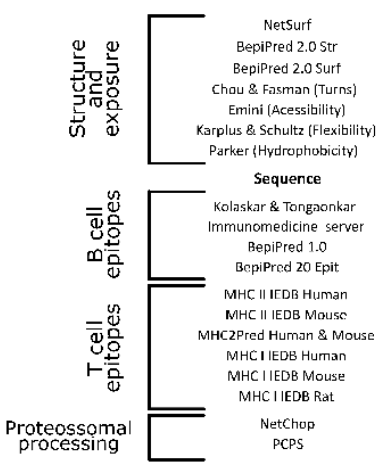

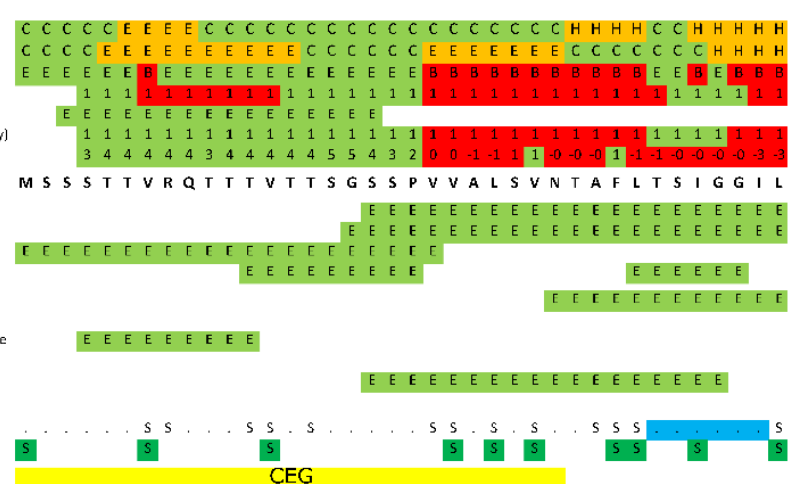

B

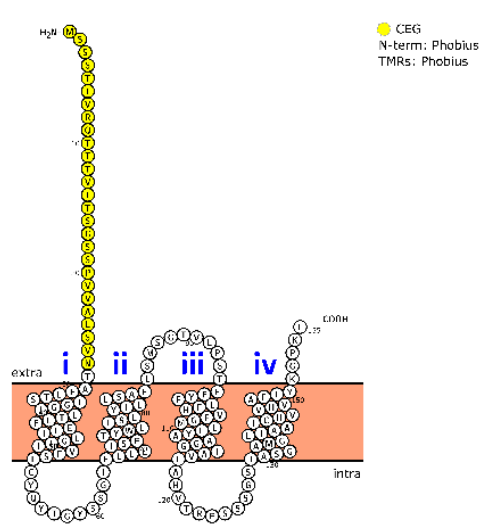

Figure 2. In silico analysis of the putative transmembrane MARVEL protein. (A) Identification of overlapping coincident epitopes groups (CEG) using different immunoinformatic approaches. (B) Topology prediction (based on Phobious) and localization of the CEG region (yellow) in the protein structure. For detailed information, see the Supplementary material-Spreadsheet S4 and S5.

The predicted coincident epitope (MSSSTTVRQTTTVTTSGSSPVVALSVN) possesses flexibility and hydrophobicity which makes this fragment a promising candidate for synthetic production (Figure 2, Supplementary material-Spreadsheet S3). Other predictions were performed (Table 3), which indicated that the peptide alone is alkaline with a high probability to be unstable and hydrophobic. Nevertheless, peptide bioengineering by selection of a compatible carrier protein or linkage to other promising targets may contribute towards alleviating such drawbacks.

This peptide has more thermostability and solubility than Bm86-derived peptide. It also has low probability in causing allergic host reactions and hemolysis. Further, it can be anti-angiogenic or toxic. These are all characteristics that improve the use of this antigen for vaccine administration.

\subsection{Putative Evasin}

Other studies have mentioned that evasins are a secreted salivary glycoprotein that enables the endurance of tick feeding by suppressing the host immune response [106]. 
During blood feeding, such molecules are injected into the tick bite site and bind to the host chemokines to inhibit its function, resulting in a prevention of chemotaxis of leukocytes and subverting the host anti-inflammatory immune response associated to this phenomenon [106]. Besides, evasins can be ubiquitously expressed by a wide variety of tick species, constituting a promising target as an anti-tick vaccine that needs to be explored $[48,106]$.

The putative evasin identified in this study contained an N-terminal signal peptide and no transmembrane helices (Table 2), suggesting that it might be a secretory protein. Moreover, this sequence has high homology to an evasin protein from Rhipicephalus microplus (AST14849) and possess several characteristics from the evasin protein family [106], such as nine Cys residues and N-linked glycosylation, as well as putative tyrosine sulfation sites (Figure 3A, Supplementary material—Spreadsheet S4). A region following the predicted signal peptide (between pos. 29 and 70) has a low complexity structure with several exposed residues (Figure 3A, Supplementary material-Spreadsheet S4), which could facilitate epitope presentation. Predictors indicates that the protein could be potentially cleaved in some positions, e.g., pos. 26 to 36 and 98 to 103, leaving a peptide portion (37-97) to be potentially processed and presented by the MHCs. Within this secretory region, many putative epitopes can be detected and processed by B and T cells containing a few putative PTMs (i.e., phosphorylation and sulfation) (Supplementary material—Spreadsheet S4). In this predicted highly immunogenic region, a peptide (EEEIVSDEYDYTTPDLDAYTPIPGARRPSLNLGSLELGSEEEY, pos. 29 to 71) was selected to be further evaluated in silico (Table 3). Predictions revealed that this peptide is acidic and unstable upon synthesis but such can be surmounted as previously referenced, in order to benefit on the other properties, such as hydrophilicity, solubility, and having no negative impacts on the host.

\section{A}
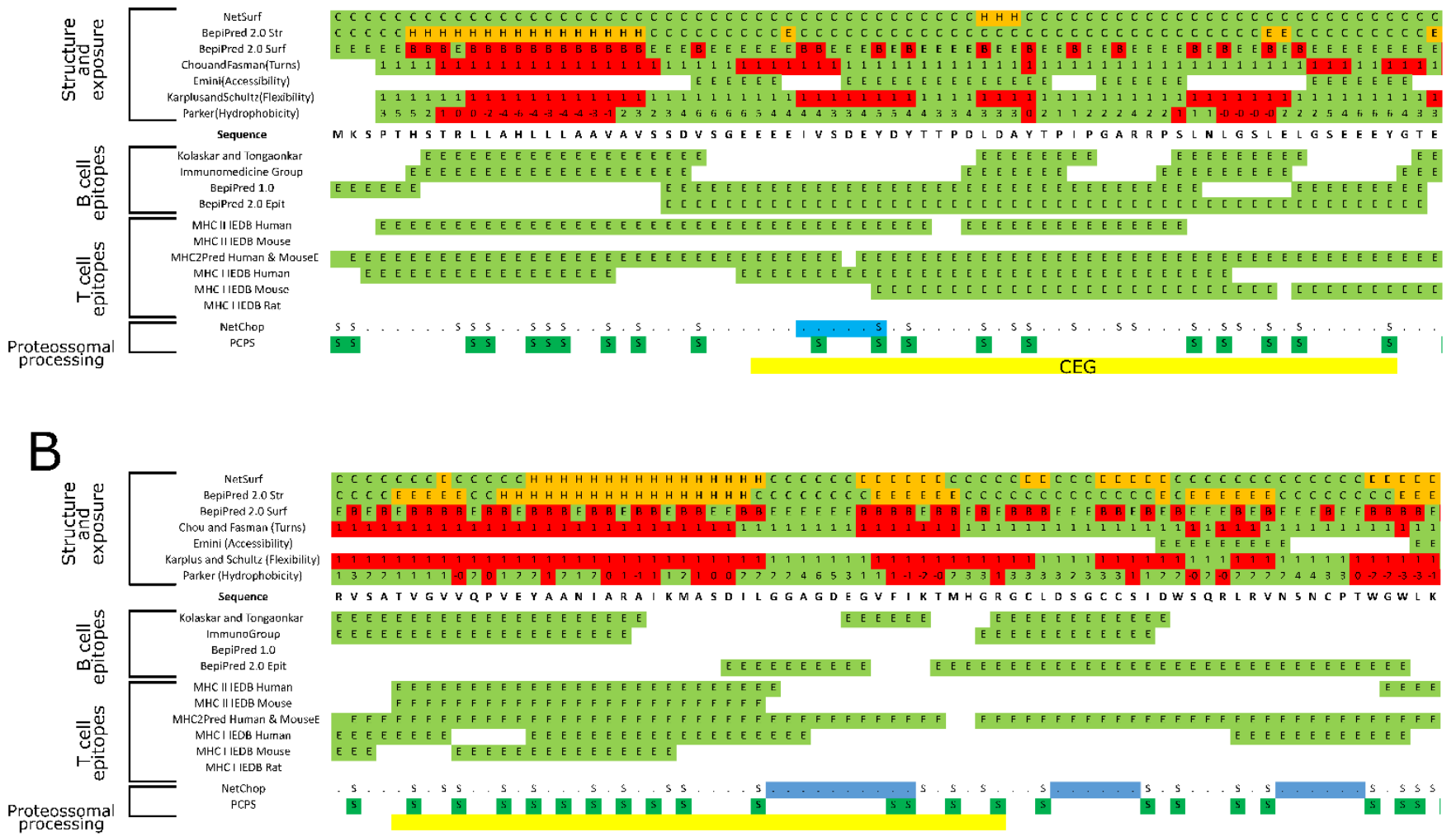

Figure 3. In silico analysis of the two putative signal proteins: EVASIN and RICIN. Identification of overlapping coincident epitopes groups (CEGs) within (A) EVASIN and (B) RICIN amino acids sequences. For detailed information see Supplementary material-Spreadsheet S4 and S5. 


\subsection{Putative Ricin}

The most characteristic though not completely conserved sequence feature of ricin $\mathrm{B}$ lectin domains is the presence of a $\mathrm{Q}-\mathrm{W}$ repeats containing an omega loop but no major segments of a helix or beta sheet throughout the sequence $[107,108]$. The primary structure of ricin proteins has shown the presence of a similar domain in many carbohydrate-recognition proteins like plant, fungi, and bacteria AB-toxins, glycosidases, or proteases [107-109]. Proteins containing such domains are linked to cytotoxicity [110,111], cytoadhering [112], and possess immunomodulatory properties [113-115]. From the dataset, one sequence shows similarity to a ricin B lectin domain (Table 2), but no Q-W repeats were found. The 133 amino acid sequence contains a signal peptide and no transmembrane helices (Table 2), indicating that it might be secreted. Myristoylation and phosphorylation PTMs were predicted in this sequence (Supplementary material-Spreadsheet S5). Even with a complex structure with alpha helixes and beta sheets that reduces the exposure of epitopes, this sequence has regions that are likely to be recognized by $\mathrm{B}$ cell receptors, as well as MHC I and MHC II receptors of different organisms (Figure 3B, Supplementary material-Spreadsheet S5). We identified an $\mathrm{N}$-terminal peptide region (TVGVVQPVEYAANIARAIKMASDILGGAGDEGVFIKTMHGR) that possesses more predicted $B$ and $T$ cell epitopes than the remaining sequence and flanked by an enzymatic cleavage site. Most of the predictors indicated that even with some undesirable characteristics (such as instability index and GRAVY), this peptide has a $\mathrm{pI}$ closer to seven as the SBm $7462{ }^{\circledR}$ peptide, could be thermostable, soluble, and present no harmful properties to the host (Table 3).

\section{Conclusions and Future Perspectives}

Transmission-blocking vaccines are considered essential tools for interrupting disease transmission. An immunized host produces inhibitory antibodies against pathogen/vector antigens that are ingested by the vector during blood feeding, interfering ultimately with vector competence and disease transmission [18]. The cellular pathway is compromised since the antibodies alter the activity or signal transduction of proteins through a physical block $[116,117]$. The discovery of new antigens is a prerequisite in developing new diagnostics and vaccines for disease surveillance and control. Reverse vaccinology is a preferable approach to overcome the time and resources required to obtain promising candidates. However, there is an urgent need to develop a pipeline to run multiple algorithms in a single platform focused on tick research, including information on tick omics data, vertebrate hosts immune databases (from livestock, domestic animals, humans, including information about the epitope repertoire, and broad population coverage), and proteins from transmitted pathogens.

This study combines the power of several bioinformatics tools to establish a rational pipeline for vaccine antigen discovery. Focusing on peptide design will greatly reduce the cost of a putative vaccine and enhance its accessibility to the community, since smaller biomolecules are easier to synthetize and store [118]. Thus, three peptides that showed the desired characteristics were identified for further testing as next-generation vaccine targets.

These promising antigens will be tested in a follow-up study, yet prior to vaccination trials, a thorough investigation should be conducted to survey the humoral immune response by animals from tick endemic regions to these peptides. A preexistent humoral response to the antigens identified here, within an endemic area, will demonstrate that such molecules do not protect the host from tick infestation. Alternatively, an absence of an established and natural humoral response to these peptides might lend weight their use in a new protective strategy or even as diagnostic markers. Interestingly, the evaluation of the expression of such targets in cells, different tissues/fluids, and developmental stages of $R$. bursa tick species, could elucidate their applicability as broad-spectrum tick antigens. Several approaches to elucidate or validate the in vivo cellular localization (e.g., immunofluorescence and western-blot assays), protein structure (e.g., crystallography), and protein-protein interactions (e.g., yeast two-hybrid, etc.) could be conducted 
in future for top selected predicted targets. Pilot vaccination trials are needed to in vivo validate the immunogenicity of peptides where different aspects should be taken in account, such as antigen design/production (peptide, native protein, synthetic, polymers, type of host expression system, recombination with other promising antigens, linkers, etc.), its administration (route/system, dose, adjuvant), the host response (humoral and cellular immune response, physiological and clinical responses), and the influence on tick behavior and physiological features.

Supplementary Materials: The following are available online at https:/ / www.mdpi.com/2227-905 9/9/4/363/s1, Spreadsheet S1: Screening of assembled transcripts containing membrane-related regions, regarding protein antigenicity, homology to vertebrate hosts, cell localization, and annotated function. Spreadsheet S2: Screening of assembled transcripts containing signal peptides, regarding protein antigenicity, homology to vertebrate hosts, cell localization, and annotated function. Spreadsheet S3: Detailed information regarding putative MARVEL in silico characterization, including protein structure and putative epitope exposure (B and T cell epitopes). Spreadsheet S4: Detailed information regarding putative EVASIN in silico characterization, including protein structure, putative epitope exposure (B and T cell epitopes). Spreadsheet S5: Detailed information regarding putative RICIN in silico characterization, including protein structure, putative epitope exposure (B and T cell epitopes).

Author Contributions: Conceptualization, J.C., S.A. and A.D.; data curation, N.A.O.; formal analysis, J.C. and G.S.; funding acquisition, S.A. and A.D.; investigation, J.C., G.S. and C.S.; methodology, J.C., C.S., C.M.-O., S.A. and A.D.; supervision, C.M.-O., S.A. and A.D.; visualization, J.C. and G.S.; writing-original draft preparation, J.C. and G.S., writing-review and editing, C.S., S.A. and A.D. All authors have read and agreed to the published version of the manuscript.

Funding: This study was funded by Fundação para a Ciência e Tecnologia (FCT) under the project TickOmic (PTDC/CVT-CVT/29073/2017). J.C. is a recipient of Ph.D. grant supported by the FCT (SFRH/BD/121946/2016).

Institutional Review Board Statement: Not applicable.

Informed Consent Statement: Not applicable.

Data Availability Statement: The data presented in this study is available as supplementary material that can be found at www.mdpi.com/xxx/s1.

Acknowledgments: Authors would like to acknowledge FCT for funding the R\&D Centre, Global Health and Tropical Medicine (GHTM - UID/04413/2020).

Conflicts of Interest: The authors declare no conflict of interest.

\section{References}

1. Swei, A.; Couper, L.I.; Coffey, L.L.; Kapan, D.; Bennett, S. Patterns, Drivers, and Challenges of Vector-Borne Disease Emergence. Vector-Borne Zoonotic Dis. 2020, 20, 159-170. [CrossRef]

2. Jaime Betancur Hurtado, O.; Giraldo-Ríos, C. Economic and Health Impact of the Ticks in Production Animals. Ticks Tick-Borne Pathog. 2019. [CrossRef]

3. Madreseh-Ghahfarokhi, S.; Dehghani-Samani, A.; Pirali, Y.; Dehghani-Samani, A. Zingiber officinalis and Eucalyptus globulus, Potent Lethal/Repellent Agents against Rhipicephalus bursa, Probable Carrier for Zoonosis. J. Arthropod-Borne Dis. 2019, 13, 223. [CrossRef]

4. Sevinc, F.; Sevinc, M.; Ekici, O.D.; Yildiz, R.; Isik, N.; Aydogdu, U. Babesia ovis infections: Detailed clinical and laboratory observations in the pre- and post-treatment periods of 97 field cases. Vet. Parasitol. 2013, 191, 35-43. [CrossRef]

5. Erster, O.; Roth, A.; Wolkomirsky, R.; Leibovich, B.; Savitzky, I.; Shkap, V. Transmission of Babesia ovis by different Rhipicephalus bursa developmental stages and infected blood injection. Ticks Tick-Borne Dis. 2016, 7, 13-19. [CrossRef] [PubMed]

6. Lonc, E.; Guz-Regner, K.; Kiewra, D.; Szczepanska, A. Insight into Tick Biocontrol with Special Regard to Fungi. Ann Parasitol. 2014, 60, 169-177. [PubMed]

7. Banumathi, B.; Vaseeharan, B.; Rajasekar, P.; Prabhu, N.M.; Ramasamy, P.; Murugan, K.; Canale, A.; Benelli, G. Exploitation of chemical, herbal and nanoformulated acaricides to control the cattle tick, Rhipicephalus (Boophilus) microplus-A review. Vet. Parasitol. 2017, 244, 102-110. [CrossRef] [PubMed]

8. Benelli, G.; Pavela, R.; Canale, A.; Mehlhorn, H. Tick repellents and acaricides of botanical origin: A green roadmap to control tick-borne diseases? Parasitol. Res. 2016, 115, 2545-2560. [CrossRef] 
9. Otto, P.I.; Guimarães, S.E.F.; Verardo, L.L.; Azevedo, A.L.S.; Vandenplas, J.; Soares, A.C.C.; Sevillano, C.A.; Veroneze, R.; de Fatima, A.; Pires, M.; et al. Genome-wide association studies for tick resistance in Bos taurus $\times$ Bos indicus crossbred cattle: A deeper look into this intricate mechanism. J. Dairy Sci. 2018, 101, 11020-11032. [CrossRef]

10. Shrivastava, N.; Verma, A.; Dash, P.K. Identification of functional epitopes of structural proteins and in-silico designing of dual acting multiepitope anti-tick vaccine against emerging Crimean-Congo hemorrhagic fever virus. Eur. J. Pharm. Sci. 2020, 151, 105396. [CrossRef] [PubMed]

11. Rodríguez Mallón, A.; Javier González, L.; Encinosa Guzmán, P.E.; Bechara, G.H.; Sanches, G.S.; Pousa, S.; Cabrera, G.; Cabrales, A.; Garay, H.; Mejías, R.; et al. Functional and Mass Spectrometric Evaluation of an Anti-Tick Antigen Based on the P0 Peptide Conjugated to Bm86 Protein. Pathogens 2020, 9, 513. [CrossRef] [PubMed]

12. Kasaija, P.D.; Contreras, M.; Kabi, F.; Mugerwa, S.; de la Fuente, J. de la Vaccination with Recombinant Subolesin Antigens Provides Cross-Tick Species Protection in Bos indicus and Crossbred Cattle in Uganda. Vaccines 2020, 8, 319. [CrossRef]

13. Ullah, M.A.; Sarkar, B.; Islam, S.S. Exploiting the reverse vaccinology approach to design novel subunit vaccines against Ebola virus. Immunobiology 2020, 225, 151949. [CrossRef]

14. Stutzer, C.; Richards, S.A.; Ferreira, M.; Baron, S.; Maritz-Olivier, C. Metazoan Parasite Vaccines: Present Status and Future Prospects. Front. Cell. Infect. Microbiol. 2018, 8, 67. [CrossRef] [PubMed]

15. Obregón Alvarez, D.; Corona-González, B.; Rodríguez-Mallón, A.; Rodríguez Gonzalez, I.; Alfonso, P.; Noda Ramos, A.A.; Díaz-Sánchez, A.A.; González Navarrete, M.; Rodríguez Fernández, R.; Méndez Mellor, L.; et al. Ticks and Tick-Borne Diseases in Cuba, Half a Century of Scientific Research. Pathogens 2020, 9, 616. [CrossRef] [PubMed]

16. De la Fuente, J.; Estrada-Peña, A. Why New Vaccines for the Control of Ectoparasite Vectors Have Not Been Registered and Commercialized? Vaccines 2019, 7, 75. [CrossRef] [PubMed]

17. De la Fuente, J.; Estrada-Peña, A.; Contreras, M. Modeling tick vaccines: A key tool to improve protection efficacy. Expert Rev. Vaccines 2020, 19, 217-225. [CrossRef]

18. Armistead, J.S.; Morlais, I.; Mathias, D.K.; Jardim, J.G.; Joy, J.; Fridman, A.; Finnefrock, A.C.; Bagchi, A.; Plebanski, M.; Scorpio, D.G.; et al. Antibodies to a single, conserved epitope in Anopheles APN1 inhibit universal transmission of Plasmodium falciparum and Plasmodium vivax malaria. Infect. Immun. 2014, 82, 818-829. [CrossRef] [PubMed]

19. Bhowmick, B.; Han, Q. Understanding Tick Biology and Its Implications in Anti-tick and Transmission Blocking Vaccines Against Tick-Borne Pathogens. Front. Vet. Sci. 2020, 7, 319. [CrossRef] [PubMed]

20. Lavazec, C.; Bourgouin, C. Mosquito-based transmission blocking vaccines for interrupting Plasmodium development. Microbes Infect. 2008, 10, 845-849. [CrossRef]

21. Rappuoli, R.; Bottomley, M.J.; D’Oro, U.; Finco, O.; De Gregorio, E. Reverse vaccinology 2.0: Human immunology instructs vaccine antigen design. J. Exp. Med. 2016, 213, 469-481. [CrossRef]

22. Forthal, D.N. Functions of antibodies. Microbiol. Spectrum. 2014, 2. [CrossRef]

23. Rand, K.N.; Moore, T.; Sriskantha, A.; Spring, K.; Tellam, R.; Willadsen, P.; Cobon, G.S. Cloning and expression of a protective antigen from the cattle tick Boophilus microplus. Proc. Natl. Acad. Sci. USA 1989, 86, 9657-9661. [CrossRef]

24. Willadsen, P.; Riding, G.A.; McKenna, R.V.; Kemp, D.H.; Tellam, R.L.; Nielsen, J.N.; Lahnstein, J.; Cobon, G.S.; Gough, J.M. Immunologic control of a parasitic arthropod. Identification of a protective antigen from Boophilus microplus. J. Immunol. 1989, 143, 1346-1351. [PubMed]

25. Lew-Tabor, A.E.; Rodriguez Valle, M. A review of reverse vaccinology approaches for the development of vaccines against ticks and tick borne diseases. Ticks Tick-Borne Dis. 2016, 7, 573-585. [CrossRef] [PubMed]

26. Obolo-Mvoulouga, P.; Oleaga, A.; Manzano-Román, R.; Pérez-Sánchez, R. Evaluation of the protective efficacy of Ornithodoros moubata midgut membrane antigens selected using omics and in silico prediction algorithms. Ticks Tick-Borne Dis. 2018, 9, 1158-1172. [CrossRef] [PubMed]

27. De la Fuente, J.; Almazán, C.; Canales, M.; de la Lastra, J.; Kocan, K.; Willadsen, P. A ten-year review of commercial vaccine performance for control of tick infestations on cattle. Anim. Health Res. Rev. 2007, 8, 23. [CrossRef] [PubMed]

28. María, R.R.; Arturo, C.J.; Alicia, J.A.; Paulina, M.G.; Gerardo, A.O. The Impact of Bioinformatics on Vaccine Design and Development. Vaccines 2017. [CrossRef]

29. Hossain, M.U.; Keya, C.A.; Das, K.C.; Hashem, A.; Omar, T.M.; Khan, M.A.; Rakib-Uz-Zaman, S.M.; Salimullah, M. An immunopharmacoinformatics approach in development of vaccine and drug candidates for West Nile Virus. Front. Chem. 2018, 6, 246. [CrossRef]

30. Maritz-Olivier, C.; van Zyl, W.; Stutzer, C. A systematic, functional genomics, and reverse vaccinology approach to the identification of vaccine candidates in the cattle tick, Rhipicephalus microplus. Ticks Tick-Borne Dis. 2012, 3, 179-187. [CrossRef]

31. Bidmos, F.A.; Siris, S.; Gladstone, C.A.; Langford, P.R. Bacterial vaccine antigen discovery in the reverse vaccinology 2.0 Era: Progress and challenges. Front. Immunol. 2018, 9, 2315. [CrossRef]

32. Rappuoli, R.; Bagnoli, F. Vaccine Design: Innovative Approaches and Novel Strategies; Horizon Scientific Press: Norfolk, UK, 2011. [CrossRef]

33. Flower, D.R. Bioinformatics for Vaccinology; John Wiley \& Sons: Hoboken, NJ, USA, 2008; ISBN 9780470027110.

34. Moriel, D.G.; Scarselli, M.; Serino, L.; Mora, M.; Rappuoli, R.; Masignani, V. Genome-based vaccine development: A short cut for the future. Hum. Vaccin. 2008, 4, 184-188. [CrossRef] [PubMed] 
35. Dadgar Pakdel, J.; Zakeri, S.; Raz, A.; Dinparast Djadid, N. Identification, molecular characterization and expression of aminopeptidase N-1 (APN-1) from Anopheles stephensi in SF9 cell line as a candidate molecule for developing a vaccine that interrupt malaria transmission. Malar. J. 2020, 19, 1-19. [CrossRef]

36. Elton, C.M.; Rodriguez, M.; Ben Mamoun, C.; Lobo, C.A.; Wright, G.J. A library of recombinant Babesia microti cell surface and secreted proteins for diagnostics discovery and reverse vaccinology. Int. J. Parasitol. 2019, 49, 115-125. [CrossRef] [PubMed]

37. Kar, P.P.; Srivastava, A. Immuno-informatics Analysis to Identify Novel Vaccine Candidates and Design of a Multi-Epitope Based Vaccine Candidate Against Theileria parasites. Front. Immunol. 2018, 9, 2213. [CrossRef] [PubMed]

38. Pritam, M.; Singh, G.; Swaroop, S.; Singh, A.K.; Singh, S.P. Exploitation of reverse vaccinology and immunoinformatics as promising platform for genome-wide screening of new effective vaccine candidates against Plasmodium falciparum. BMC Bioinform. 2019, 19, 219-230. [CrossRef]

39. E de Silva, R.F.; Ferreira, L.F.G.R.; Hernandes, M.Z.; de Brito, M.E.F.; de Oliveira, B.C.; da Silva, A.A.; de-Melo-Neto, O.P.; Rezende, A.M.; Pereira, V.R.A. Combination of in silico methods in the search for potential CD4+ and CD8+ T cell epitopes in the proteome of Leishmania braziliensis. Front. Immunol. 2016, 7, 327. [CrossRef] [PubMed]

40. Oli, A.N.; Obialor, W.O.; Ifeanyichukwu, M.O.; Odimegwu, D.C.; Okoyeh, J.N.; Emechebe, G.O.; Adejumo, S.A.; Ibeanu, G.C. Immunoinformatics and Vaccine Development: An Overview. ImmunoTargets Ther. 2020, 9, 13-30. [CrossRef] [PubMed]

41. Pérez-Sánchez, R.; Manzano-Román, R.; Obolo-Mvoulouga, P.; Oleaga, A. Function-guided selection of midgut antigens from Ornithodoros erraticus ticks and an evaluation of their protective efficacy in rabbits. Vet. Parasitol. 2019, 272, 1-12. [CrossRef]

42. Xu, Z.; Yan, Y.; Cao, J.; Zhou, Y.; Zhang, H.; Xu, Q.; Zhou, J. A family of serine protease inhibitors (serpins) and its expression profiles in the ovaries of Rhipicephalus haemaphysaloides. Infect. Genet. Evol. 2020, 84. [CrossRef]

43. Maruyama, S.R.; Garcia, G.R.; Teixeira, F.R.; Brandão, L.G.; Anderson, J.M.; Ribeiro, J.M.C.; Valenzuela, J.G.; Horackova, J.; Veríssimo, C.J.; Katiki, L.M.; et al. Mining a differential sialotranscriptome of Rhipicephalus microplus guides antigen discovery to formulate a vaccine that reduces tick infestations. Parasites Vectors 2017, 10, 206. [CrossRef] [PubMed]

44. Kotál, J.; Langhansová, H.; Lieskovská, J.; Andersen, J.F.; Francischetti, I.M.B.; Chavakis, T.; Kopecký, J.; Pedra, J.H.F.; Kotsyfakis, M.; Chmelař, J. Modulation of host immunity by tick saliva. J. Proteom. 2015, 128, 58-68. [CrossRef]

45. Francischetti, I.M.B.; Sa-Nunes, A.; Mans, B.J.; Santos, I.M.; Ribeiro, J.M.C. The role of saliva in tick feeding. Front. Biosci. 2009, 14, 2051-2088. [CrossRef]

46. Wikel, S. Ticks and tick-borne pathogens at the cutaneous interface: Host defenses, tick countermeasures, and a suitable environment for pathogen establishment. Front. Microbiol. 2013, 4, 337. [CrossRef] [PubMed]

47. Neelakanta, G.; Sultana, H. Transmission-Blocking Vaccines: Focus on Anti-Vector Vaccines against Tick-Borne Diseases. Arch. Immunol. Ther. Exp. 2015, 63, 169-179. [CrossRef]

48. Chmelar, J.; Kotál, J.; Kovaríková, A.; Kotsyfakis, M. The use of tick salivary proteins as novel therapeutics. Front. Physiol. 2019, 10, 812. [CrossRef] [PubMed]

49. Chmelař, J.; Kotál, J.; Kopecký, J.; Pedra, J.H.F.; Kotsyfakis, M. All For One and One For All on the Tick-Host Battlefield. Trends Parasitol. 2016, 32, 368-377. [CrossRef]

50. Richards, S.A.; Stutzer, C.; Bosman, A.M.; Maritz-Olivier, C. Transmembrane proteins-Mining the cattle tick transcriptome. Ticks Tick-Borne Dis. 2015, 6, 695-710. [CrossRef] [PubMed]

51. Nosrati, M.; Behbahani, M.; Mohabatkar, H. Towards the first multi-epitope recombinant vaccine against Crimean-Congo hemorrhagic fever virus: A computer-aided vaccine design approach. J. Biomed. Inform. 2019, 93, 103160. [CrossRef] [PubMed]

52. Solanki, V.; Tiwari, V. Subtractive proteomics to identify novel drug targets and reverse vaccinology for the development of chimeric vaccine against Acinetobacter baumannii. Sci. Rep. 2018, 8, 9044. [CrossRef] [PubMed]

53. Dinglasan, R.R.; Kalume, D.E.; Kanzok, S.M.; Ghosh, A.K.; Muratova, O.; Pandey, A.; Jacobs-Lorena, M. Disruption of Plasmodium falciparum development by antibodies against a conserved mosquito midgut antigen. Proc. Natl. Acad. Sci. USA 2007, 104, 13461-13466. [CrossRef] [PubMed]

54. Couto, J.; Tonk, M.; Ferrolho, J.; Antunes, S.; Vilcinskas, A.; de la Fuente, J.; Domingos, A.; Cabezas-Cruz, A. Antiplasmodial activity of tick defensins in a mouse model of malaria. Ticks Tick-Borne Dis. 2018. [CrossRef] [PubMed]

55. Hajdusek, O.; Almazán, C.; Loosova, G.; Villar, M.; Canales, M.; Grubhoffer, L.; Kopacek, P.; de la Fuente, J. Characterization of ferritin 2 for the control of tick infestations. Vaccine 2010, 28, 2993-2998. [CrossRef] [PubMed]

56. Dai, J.; Wang, P.; Adusumilli, S.; Booth, C.J.; Narasimhan, S.; Anguita, J.; Fikrig, E. Antibodies against a Tick Protein, Salp15, Protect Mice from the Lyme Disease Agent. Cell Host Microbe 2009, 6, 482-492. [CrossRef]

57. Alvarez, P.; Leguizamón, M.S.; Buscaglia, C.A.; Pitcovsky, T.A.; Campetella, O. Multiple overlapping epitopes in the repetitive unit of the shed acute-phase antigen from Trypanosoma cruzi enhance its immunogenic properties. Infect. Immun. 2001, 69, 7946-7949. [CrossRef] [PubMed]

58. Sela-Culang, I.; Benhnia, M.R.E.I.; Matho, M.H.; Kaever, T.; Maybeno, M.; Schlossman, A.; Nimrod, G.; Li, S.; Xiang, Y.; Zajonc, D.; et al. Using a combined computational-experimental approach to predict antibody-specific B cell epitopes. Structure 2014, 22, 646-657. [CrossRef] [PubMed]

59. Antunes, S.; Couto, J.; Ferrolho, J.; Rodrigues, F.; Nobre, J.; Santos, A.S.; Margarida Santos-Silva, M.; de la Fuente, J.; Domingos, A. Rhipicephalus bursa sialotranscriptomic response to blood feeding and Babesia ovis infection: Identification of candidate protective antigens. Front. Cell. Infect. Microbiol. 2018, 8, 1-17. [CrossRef] [PubMed] 
60. Bolger, A.; Lohse, M.; Usadel, B. Trimmomatic: A flexible trimmer for Illumina sequence data. Bioinformatics 2014, 30, 2114-2120. [CrossRef] [PubMed]

61. Grabherr, M.G.; Haas, B.J.; Yassour, M.; Levin, J.Z.; Thompson, D.A.; Amit, I.; Adiconis, X.; Fan, L.; Raychowdhury, R.; Zeng, Q.; et al. Full-length transcriptome assembly from RNA-Seq data without a reference genome. Nat. Biotechnol. $2011,29,644-652$. [CrossRef] [PubMed]

62. Simão, F.; Waterhouse, R.; Ioannidis, P.; Kriventseva, E.; Zdobnov, E. BUSCO: Assessing genome assembly and annotation completeness with single-copy orthologs. Bioinformatics 2015, 31, 3210-3212. [CrossRef] [PubMed]

63. Jones, P.; Binns, D.; Chang, H.; Fraser, M.; Li, W.; McAnulla, C.; McWilliam, H.; Maslen, J.; Mitchell, A.; Nuka, G.; et al. InterProScan 5: Genome-scale protein function classification. Bioinformatics 2014, 30, 1236-1240. [CrossRef]

64. Petersen, T.; Brunak, S.; von Heijne, G.; Nielsen, H. SignalP 4.0: Discriminating signal peptides from transmembrane regions. Nat. Methods 2011, 8, 785-786. [CrossRef] [PubMed]

65. Krogh, A.; Larsson, B.; von Heijne, G.; Sonnhammer, E.L. Predicting transmembrane protein topology with a hidden Markov model: Application to complete genomes. J. Mol. Biol. 2001, 305, 567-580. [CrossRef] [PubMed]

66. Sonnhammer, E.L.; von Heijne, G.; Krogh, A. A hidden Markov model for predicting transmembrane helices in protein sequences. Proc. Int. Conf. Intell. Syst. Mol. Biol. 1998, 6, 175-182. [PubMed]

67. Fu, L.; Niu, B.; Zhu, Z.; Wu, S.; Li, W. CD-HIT: Accelerated for clustering the next-generation sequencing data. Bioinformatics 2012, 28, 3150-3152. [CrossRef]

68. Doytchinova, I.A.; Flower, D.R. VaxiJen: A server for prediction of protective antigens, tumour antigens and subunit vaccines. BMC Bioinform. 2007, 8, 4. [CrossRef] [PubMed]

69. Yu, C.-S.; Chen, Y.-C.; Lu, C.-H.; Hwang, J.-K. Prediction of protein subcellular localization. Proteins Struct. Funct. Bioinform. 2006, 64, 643-651. [CrossRef]

70. Horton, P.; Park, K.-J.; Obayashi, T.; Fujita, N.; Harada, H.; Adams-Collier, C.J.; Nakai, K. WoLF PSORT: Protein localization predictor. Nucleic Acids Res. 2007, 35, W585-W587. [CrossRef]

71. Almagro Armenteros, J.J.; Tsirigos, K.D.; Sønderby, C.K.; Petersen, T.N.; Winther, O.; Brunak, S.; von Heijne, G.; Nielsen, H. SignalP 5.0 improves signal peptide predictions using deep neural networks. Nat. Biotechnol. 2019, 37, 420-423. [CrossRef] [PubMed]

72. Eisenhaber, B.; Bork, P.; Eisenhaber, F. Sequence properties of GPI-anchored proteins near the omega-site: Constraints for the polypeptide binding site of the putative transamidase. Protein Eng. Des. Sel. 1998, 11, 1155-1161. [CrossRef]

73. Fankhauser, N.; Maser, P. Identification of GPI anchor attachment signals by a Kohonen self-organizing map. Bioinformatics 2005, 21, 1846-1852. [CrossRef]

74. Madeira, F.; Park, Y.M.; Lee, J.; Buso, N.; Gur, T.; Madhusoodanan, N.; Basutkar, P.; Tivey, A.R.N.; Potter, S.C.; Finn, R.D.; et al. The EMBL-EBI search and sequence analysis tools APIs in 2019. Nucleic Acids Res. 2019, 47, W636-W641. [CrossRef]

75. Dobson, L.; Reményi, I.; Tusnády, G.E. CCTOP: A Consensus Constrained TOPology prediction web server. Nucleic Acids Res. 2015, 43, W408-W412. [CrossRef]

76. Couto, J.; Villar, M.; Mateos-Hernández, L.; Ferrolho, J.; Sanches, G.; Sofia Santos, A.; Santos-Silva, M.; Nobre, J.; Moreira, O.; Antunes, S.; et al. Quantitative Proteomics Identifies Metabolic Pathways Affected by Babesia Infection and Blood Feeding in the Sialoproteome of the Vector Rhipicephalus bursa. Vaccines 2020, 8, 91. [CrossRef]

77. Jespersen, M.C.; Peters, B.; Nielsen, M.; Marcatili, P. BepiPred-2.0: Improving sequence-based B-cell epitope prediction using conformational epitopes. Nucleic Acids Res. 2017, 45, W24-W29. [CrossRef] [PubMed]

78. Chou, P.Y.; Fasman, G.D. Prediction of the secondary structure of proteins from their amino acid sequence. Adv. Enzymol. Relat. Areas Mol. Biol. 1978, 47, 45-148. [CrossRef] [PubMed]

79. Karplus, P.A.; Schulz, G.E. Prediction of chain flexibility in proteins. Naturwissenschaften 1985, 72, 212-213. [CrossRef]

80. Parker, J.M.; Guo, D.; Hodges, R.S. New hydrophilicity scale derived from high-performance liquid chromatography peptide retention data: Correlation of predicted surface residues with antigenicity and X-ray-derived accessible sites. Biochemistry 1986, 25, 5425-5432. [CrossRef]

81. Kolaskar, A.; Tongaonkar, P. A semi-empirical method for prediction of antigenic determinants on protein antigens. FEBS Lett. 1990, 276, 172-174. [CrossRef]

82. Nielsen, M.; Lundegaard, C.; Lund, O.; Keşmir, C. The role of the proteasome in generating cytotoxic T-cell epitopes: Insights obtained from improved predictions of proteasomal cleavage. Immunogenetics 2005, 57, 33-41. [CrossRef]

83. Dimitrov, I.; Naneva, L.; Doytchinova, I.; Bangov, I. AllergenFP: Allergenicity prediction by descriptor fingerprints. Bioinformatics 2014, 30, 846-851. [CrossRef] [PubMed]

84. Dimitrov, I.; Bangov, I.; Flower, D.R.; Doytchinova, I. AllerTOP v.2-a server for in silico prediction of allergens. J. Mol. Model. 2014, 20, 2278. [CrossRef] [PubMed]

85. Maurer-Stroh, S.; Krutz, N.; Kern, P.; Gunalan, V.; Nguyen, M.; Limviphuvadh, V.; Eisenhaber, F.; Gerberick, G. AllerCatPro-prediction of protein allergenicity potential from the protein sequence. Bioinformatics 2019, 35, 3020-3027. [CrossRef] [PubMed]

86. Hebditch, M.; Carballo-Amador, M.A.; Charonis, S.; Curtis, R.; Warwicker, J. Protein-Sol: A web tool for predicting protein solubility from sequence. Bioinformatics 2017, 33, 3098-3100. [CrossRef]

87. Kurgan, L.; Razib, A.A.; Aghakhani, S.; Dick, S.; Mizianty, M.; Jahandideh, S. Crystalp2: Sequence-based protein crystallization propensity prediction. BMC Struct. Biol. 2009, 9, 50. [CrossRef] [PubMed] 
88. Pejaver, V.; Hsu, W.L.; Xin, F.; Dunker, A.K.; Uversky, V.N.; Radivojac, P. The structural and functional signatures of proteins that undergo multiple events of post-translational modification. Protein Sci. 2014, 23, 1077-1093. [CrossRef] [PubMed]

89. Sigrist, C.; De Castro, E.; Cerutti, L.; Cuche, B.; Hulo, N.; Bridge, A.; Bougueleret, L.; Xenarios, I. New and continuing developments at PROSITE. Nucleic Acids Res. 2012, 41, D344-D347. [CrossRef] [PubMed]

90. Audagnotto, M.; Dal Peraro, M. Protein post-translational modifications: In silico prediction tools and molecular modeling Comput. Struct. Biotechnol. J. 2017, 15, 307-319. [CrossRef]

91. Chaudhary, K.; Kumar, R.; Singh, S.; Tuknait, A.; Gautam, A.; Mathur, D.; Anand, P.; Varshney, G.C.; Raghava, G.P.S. A web server and mobile app for computing hemolytic potency of peptides. Sci. Rep. 2016, 6, 1-13. [CrossRef] [PubMed]

92. Ettayapuram Ramaprasad, A.S.; Singh, S.; Gajendra, P.S.R.; Venkatesan, S. AntiAngioPred: A Server for Prediction of AntiAngiogenic Peptides. PLoS ONE 2015, 10, e0136990. [CrossRef]

93. Gupta, S.; Kapoor, P.; Chaudhary, K.; Gautam, A.; Kumar, R.; Raghava, G.P.S. In Silico Approach for Predicting Toxicity of Peptides and Proteins. PLoS ONE 2013, 8, e73957. [CrossRef] [PubMed]

94. Patarroyo, J.H.; Portela, R.W.; De Castro, R.O.; Couto Pimentel, J.; Guzman, F.; Patarroyo, M.E.; Vargas, M.I.; Prates, A.A.; Dias Mendes, M.A. Immunization of cattle with synthetic peptides derived from the Boophilus microplus gut protein (Bm86). Vet. Immunol. Immunopathol. 2002, 88, 163-172. [CrossRef]

95. Patarroyo, S.J.H.; de Sousa Neves, E.; Fidelis, C.F.; Tafur-Gómez, G.A.; de Araujo, L.; Vargas, M.I.; Sossai, S.; Prates-Patarroyo, P.A. Bovine immunisation with a recombinant peptide derived from synthetic SBm7462 ${ }^{\circledR}$ (Bm86 epitope construct) immunogen for Rhipicephalus microplus control. Ticks Tick-Borne Dis. 2020, 11, 101461. [CrossRef] [PubMed]

96. Seppey, M.; Manni, M.; Zdobnov, E.M. BUSCO: Assessing genome assembly and annotation completeness. In Methods in Molecular Biology; Humana Press Inc: New York, NY, USA, 2019; Volume 1962, pp. 227-245. [CrossRef]

97. Baron, S.; Barrero, R.A.; Black, M.; Bellgard, M.I.; van Dalen, E.; Maritz-Olivier, C. Differentially expressed genes in response to amitraz treatment suggests a proposed model of resistance to amitraz in R. decoloratus ticks. Int. J. Parasitol. Drugs Drug Resist. 2018, 8, 361-371. [CrossRef] [PubMed]

98. Usmani, S.S.; Kumar, R.; Bhalla, S.; Kumar, V.; Raghava, G.P.S. In Silico Tools and Databases for Designing Peptide-Based Vaccine and Drugs. In Advances in Protein Chemistry and Structural Biology; Elsevier: Amsterdam, The Netherlands, 2018; Volume 112, pp. 221-263.

99. Zhao, L.; Wu, S.; Jiang, J.; Li, W.; Luo, J.; Li, J. Novel overlapping subgraph clustering for the detection of antigen epitopes. Bioinformatics 2018, 34, 2061-2068. [CrossRef]

100. Bremel, R.D.; Homan, E.J. Recognition of Higher Order Patterns in Proteins: Immunologic Kernels. PLoS ONE 2013,8 , e70115. [CrossRef]

101. De la Fuente, J.; Antunes, S.; Bonnet, S.; Cabezas-Cruz, A.; Domingos, A.G.; Estrada-Peña, A.; Johnson, N.; Kocan, K.M.; Mansfield, K.L.; Nijhof, A.M.; et al. Tick-Pathogen Interactions and Vector Competence: Identification of Molecular Drivers for Tick-Borne Diseases. Front. Cell. Infect. Microbiol. 2017, 7, 114. [CrossRef] [PubMed]

102. Farrell, D.; Jones, G.; Pirson, C.; Malone, K.; Rue-Albrecht, K.; Chubb, A.J.; Vordermeier, M.; Gordon, S.V. Integrated computational prediction and experimental validation identifies promiscuous $\mathrm{T}$ cell epitopes in the proteome of Mycobacterium bovis. Microb. Genom. 2016, 2, e000071. [CrossRef] [PubMed]

103. Kardani, K.; Bolhassani, A.; Namvar, A. An overview of in silico vaccine design against different pathogens and cancer. Expert Rev. Vaccines 2020, 1-28. [CrossRef] [PubMed]

104. Caraballo, L.; Coronado, S. Parasite allergens. Mol. Immunol. 2018, 100, 113-119. [CrossRef] [PubMed]

105. Sánchez-Pulido, L.; Martín-Belmonte, F.; Valencia, A.; Alonso, M.A. MARVEL: A conserved domain involved in membrane apposition events. Trends Biochem. Sci. 2002, 27, 599-601. [CrossRef]

106. Hayward, J.; Sanchez, J.; Perry, A.; Huang, C.; Rodriguez Valle, M.; Canals, M.; Payne, R.J.; Stone, M.J. Ticks from diverse genera encode chemokine-inhibitory evasin proteins. J. Biol. Chem. 2017, 292, 15670-15680. [CrossRef] [PubMed]

107. Rutenber, E.; Ready, M.; Robertus, J.D. Structure and evolution of ricin B chain. Nature 1987, 326, 624-626. [CrossRef]

108. Hazes, B.; Read, R.J. A mosquitocidal toxin with a ricin-like cell-binding domain. Nat. Struct. Biol. 1995, 2, 358-359. [CrossRef]

109. Hirabayashi, J.; Dutta, S.K.; Kasai, K.I. Novel galactose-binding proteins in Annelida: Characterization of 29- kDa tandem repeat-type lectins from the earthworm Lumbricus terrestris. J. Biol. Chem. 1998, 273, 14450-14460. [CrossRef]

110. Hutson, R.A.; Zhou, Y.; Collins, M.D.; Johnson, E.A.; Hatheway, C.L.; Sugiyama, H. Genetic characterization of Clostridium botulinum type A containing silent type B neurotoxin gene sequences. J. Biol. Chem. 1996, 271, 10786-10792. [CrossRef] [PubMed]

111. Eyigor, A.; Dawson, K.A.; Langlois, B.E.; Pickett, C.L. Cytolethal distending toxin genes in Campylobacter jejuni and Campylobacter coli isolates: Detection and analysis by PCR. J. Clin. Microbiol. 1999, 37, 1646-1650. [CrossRef]

112. Bastos, R.G.; Suarez, C.E.; Laughery, J.M.; Johnson, W.C.; Ueti, M.W.; Knowles, D.P. Differential Expression of Three Members of the Multidomain Adhesion CCp Family in Babesia bigemina, Babesia bovis and Theileria equi. PLoS ONE 2013, 8, e67765. [CrossRef] [PubMed]

113. Babenko, V.V.; Podgorny, O.V.; Manuvera, V.A.; Kasianov, A.S.; Manolov, A.I.; Grafskaia, E.N.; Shirokov, D.A.; Kurdyumov, A.S.; Vinogradov, D.V.; Nikitina, A.S.; et al. Draft genome sequences of Hirudo medicinalis and salivary transcriptome of three closely related medicinal leeches. BMC Genom. 2020, 21, 1-16. [CrossRef]

114. Gupta, G.S.; Gupta, R.K.; Gupta, G.S. R-Type Lectin Families. In Animal Lectins: Form, Function and Clinical Applications; Springer: Vienna, Austria, 2012; pp. 313-330. 
115. Pohleven, J.; Obermajer, N.; Sabotič, J.; Anžlovar, S.; Sepčić, K.; Kos, J.; Kralj, B.; Štrukelj, B.; Brzin, J. Purification, characterization and cloning of a ricin B-like lectin from mushroom Clitocybe nebularis with antiproliferative activity against human leukemic $\mathrm{T}$ cells. Biochim. Biophys. Acta Gen. Subj. 2009, 1790, 173-181. [CrossRef] [PubMed]

116. Adams, G.P.; Weiner, L.M. Monoclonal antibody therapy of cancer. Nat. Biotechnol. 2005, 23, 1147-1157. [CrossRef] [PubMed]

117. Slastnikova, T.A.; Ulasov, A.V.; Rosenkranz, A.A.; Sobolev, A.S. Targeted intracellular delivery of antibodies: The state of the art. Front. Pharmacol. 2018, 9, 1208. [CrossRef] [PubMed]

118. Palanisamy, N.; Lennerstrand, J. Computational Prediction of Usutu Virus E Protein B Cell and T Cell Epitopes for Potential Vaccine Development. Scand. J. Immunol. 2017, 85, 350-364. [CrossRef] [PubMed] 